\title{
USE OF HYDROCARBON REFRIGERANTS IN COLD STORES AND RECOMMENDATIONS ON FIRE PROTECTION SYSTEMS
}

\author{
SARDARPARMINDER SINGH ${ }^{1}$, D. RAMESH BABU ${ }^{2} *$, P. ISSAC PRASAD ${ }^{3} \&$ K. V. NARASIMHA RAO ${ }^{4}$ \\ ${ }^{1}$ Assistant Professor, Department of Business Management, S R Engineering College, Warangal, Telangana, India \\ ${ }^{2}$ Assistant Professor, Department of Mechanical Engineering, S R Engineering college, Warangal, Telangana, India \\ ${ }^{3,4}$ Professor, Department of Mechanical Engineering, Koneru Lakshmaiah Education Foundation, Vaddeswaram,
}

Andhra Pradesh, India

\begin{abstract}
Cold stores and controlled atmosphere stores are used for long term preservation of fruits, vegetables, grains and dry fruits. Suitable fire fighting systems are required for safe operation of these facilities. Storage structure, chemicals used as refrigerants, fruit packing materials are the major source of fire accidents. Based on a technical study in fifty cold stores/controlled atmosphere stores, analysis is done to show the status of these stores from fire safety point of view. Technical equipment, refrigeration systems, type of refrigerants used for cooling compressors, fire fighting arrangements available in existing cold stores are discussed. Recommendations are made for making cold stores safe from fire hazard in the light of global change in adopting hydrocarbon refrigerants.

KEYWORDS: Cold Storage, Controlled Atmosphere Storage, Hydro Carbon Refrigerants, Fire Safety Equipment \& Packing Materials
\end{abstract}

Received: Jun 05, 2020; Accepted: Jun 25, 2020; Published: Jul 30, 2020; Paper Id.: IJMPERDJUN2020528

\section{INTRODUCTION}

Cold Store (CS) or Controlled Atmosphere Storage (CAS) is used for preserving fruits, vegetables, grains and dry fruits. Most of the cold stores in north India store potato, apple and dry fruits apart from other fruits and vegetables. Chilli producing areas of south India are installed with cold store facilities to store dry red chillis. Several accidents happen in cold stores make lot of loss to the material stored and the cold storage facility damage. Most of the times the fire accidents make it difficult to retard the fire due to the bulk storing of combustible materials. Following features of CS/CAS are generally prone for fire accidents and needs attention.

- Cold room wall made with insulation materials like glass wool, Thermocol, Polyurethane foam (PUF), rock wool, wooden structures etc.

- Refrigerants (Both flammable and non- flammable) used in the Refrigeration cycle

- Chemicals used for plant maintenance

- Lubricants and oils used for maintenance of equipment

- Packing materials like paper, card board, wood etc. stacked and stored for the purpose of packing of fruits, vegetables or grains.

Ammonia is the most commonly used refrigerant in the cold stores, which explodes under high heat. Plant 
and machinery generate heat due their operation. Suitable ventilation is to be provided for heat dissipation so that the temperatures of the equipment and motors, compressors, etc. are kept under control.

The recent developments of cold store construction and storage of fruits is the CAS which maintains low oxygen levels and high $\mathrm{CO}_{2}$ and nitrogen levels inside the sealed storage chambers where temperature is maintained typically $0^{\circ} \mathrm{C}$ for apples. Under these conditions, any fire spark is retarded by the atmosphere inside the chambers. The existing cold stores don't have this features being only low temperature storage and oxygen levels are near $21 \%$ as ambience. The ordinary cold stores are thereby susceptible for fire accidents.

Apart from cold store building structure, other important fire prone areas are the machine or engine room where lot of equipment like compressors, pumps and motors running round the clock. These systems generate heat and necessary ventilation must be provided. A close monitoring of the health of the machines will avoid any overheating due to malfunctioning or overloading. A proper schedule of checking each and every rotating or heat generating equipment becomes necessary. Now-a-days condition monitoring using sensors are available, where signatures of the heat profiles are measured and corrective actions are taken immediately by a computer online/offline.

Some of the hydrocarbons used as refrigerants in the refrigeration systems are Ethane-R170, Butane-R600, PentaneR601, Isopentane-R601a, Isobutane-R600a, Dimethyl Ether-R-E170, Methane-R50, Propane-R290, etc.,. However these are highly flammable in nature. Any leakage of gas during charging, repairs, or any leakages during operation can make the atmosphere fire prone.

This study is aimed to find the existing facilities provided in cold stores in specific areas and make recommendations for future in the era of changing of systems to hydro-carbon based refrigeration, which needs more safety features with regard to fire protection.

\section{LITERATURE OVERVIEW}

Ramesh Babu (2014) [1] in his study highlighted about the fire safety arrangements required for controlled atmosphere storage plants consisting of low oxygen equipment, carbon di-oxide scrubbers, nitrogen generators, diesel generator sets, instrumentation and control systems used in an apple storage facility.

ASHRAE hand book (1990) [2] indicated the necessary fire safety codes required for the cold stores for safe operation.

NHB (2018) [3] in their code on cold stores, controlled atmosphere stores, pre-cooling facilities has mentioned the importance of fire safety systems in the fruit and vegetable preservation plants.

Pearson et al. (1980) [4] studied the details of causes of cold store fire accidents and suggested to specify the codes for testing of materials of construction, so that fire accidents can be reduced in cold storage plants. They gave suggestions to the International Institute of Refrigeration to go for developing safety codes specifically for cold stores.

Dragan Živanić (2019) [5] discussed thoroughly about fire accidents and its affect in warehouses. They found that improper installation or absence of sprinkler systems, sprinkler installation irregularities, compartment separation lacking, construction irregularities of warehouse, poor or bad maintenance, toxic gas evaporation levels are high, late detection of fire, absence of damage reduction plans, etc. 
Several researchers studied the projects, bio-mass tray dryers using agricultural waste material for firing and heat generating for food products like green leafy vegetables [6-10].

Cold store applications for fruit preservation like apple, mango, banana, other fruits and vegetables are thoroughly reported in the literature [11-14].

\section{MATERIALS AND METHODS}

Fifty cold stores/controlled atmosphere stores located in and around Kundli area near Delhi (which is a highly dense location for cold stores) were verified for the details of technical plant and machinery, type of refrigeration systems used, fire safety arrangements like Manual Call points(MCP's, Automatic systems, Hydrant systems etc., used by them. Based on the collected the data, Microsoft excel is used to analyze the data and make recommendations to reduce fire accidents in the light of changeover to the hydro carbon refrigerant gases, which are highly flammable and need to change the refrigerants as per Montreal and Kyoto protocol for environmental safety(Ozone depletion and Global warming).

\section{RESULTS AND DISCUSSIONS}

Table1: Details of Type of Storage Unit (Cold Store/ CA Store/ Frozen Store)

\begin{tabular}{|l|c|}
\hline \multicolumn{1}{|c|}{ Type of Store } & $\begin{array}{c}\text { \% of Type of Facility } \\
\text { (Cold Store/CA Store/Frozen Store) }\end{array}$ \\
\hline Cold store & 82 \\
\hline CA Store & 18 \\
\hline Cold store with frozen & 24 \\
\hline
\end{tabular}

From the table 1, it can be seen that cold stores are more in number compared to latest technology Controlled atmosphere stores. Some cold stores have facility for frozen goods like ice creams, green peas and meat storage. Most of these cold stores are found to be older than CA Stores. Most of them are found to be in used condition.

Table 2: Type of Refrigerants used in Cold Store Plants

\begin{tabular}{|l|c|}
\hline \multicolumn{1}{|c|}{ Refrigerant used } & \% of Cold Stores \\
\hline R717 (Ammonia) & 42 \\
\hline R-22 & 26 \\
\hline R404-A & 14 \\
\hline R134a & 12 \\
\hline Others & 6 \\
\hline
\end{tabular}

Table 2 gives the picture of refrigerants used for running the refrigeration compressor along with circuit of condenser, evaporator and circuit. 43\% of the stores are using Ammonia as refrigerant, 26\% systems are using R-22 and 14\% with R404A and $12 \%$ with R134A.

Table 3: Indicating the \% of Cold Stores Equipped with Different Fire-Fighting Equipment.

\begin{tabular}{|c|c|}
\hline Fire Safety Arrangements & $\begin{array}{l}\text { \% of Cold Stores Equipped with Different } \\
\text { Fire-Fighting Equipment }\end{array}$ \\
\hline Co2 Extinguishers & 76 \\
\hline Dry powder type extinguishers & 52 \\
\hline Fire hydrant system & 82 \\
\hline Sprinkler system in side cold room & 22 \\
\hline Sprinkler system both in cold room and Working spaces & 8 \\
\hline Automatic High pressure foam system for Electrical area & 2 \\
\hline Sand buckets only & 0 \\
\hline Combination of all above based on technical area requirements & 6 \\
\hline
\end{tabular}


From table 3, it may be seen that majority of cold stores are installed with $\mathrm{CO}_{2}$ fire extinguishers, about $52 \%$ contain Dry powder type, $82 \%$ stores equipped with fire hydrant system. Sprinkler system is installed only in $22 \%$ cases within cold rooms where fresh produce is stored. Only in one case the high pressure foam system is installed. This indicates the need to assess the safety requirements of cold stores, irrespective of old construction or newly constructed. The problem can substantially increase from fire safety point of view, when most of the stores need to retrofit or go for more eco friendly refrigerants like hydro carbons.

Table 4: Details of Provision of Sensors for Fire Detection

\begin{tabular}{|l|c|}
\hline $\begin{array}{c}\text { Sensors for Detecting Fire } \\
\text { or Smoke }\end{array}$ & $\begin{array}{c}\text { \% of Cold Stores Provided with Fire } \\
\text { Detection System }\end{array}$ \\
\hline Yes & 68 \\
\hline No & 32 \\
\hline
\end{tabular}

Table 4 gives the details of fire detection sensors installed in cold stores. Only $68 \%$ of stores are provided with sensors to detect smoke and fire. This gives the alarming situation for installing the sensors to indicate when fire occurs.

Table 5: Indicating the Details of Manual Call Points (MCP's) Installed

\begin{tabular}{|c|c|}
\hline $\begin{array}{c}\text { Provision of Manual } \\
\text { Call Points }\end{array}$ & $\begin{array}{c}\text { \% of Cold Stores Provided } \\
\text { with MCP's }\end{array}$ \\
\hline Yes & 86 \\
\hline No & 14 \\
\hline
\end{tabular}

From table 5 we can see the provision of MCP's. About $86 \%$ of stores are provided with MCP's. The workers working inside the store can break the glass and press the button to activate the siren to indicate that the fire broke.

Table 6: Details of Persons Trained in Fire Safety

\begin{tabular}{|l|c|}
\hline Number of Safety Trained People & $\begin{array}{c}\text { \% of Stored with Trained People } \\
\text { on Fire Safety }\end{array}$ \\
\hline One & 56 \\
\hline Two & 26 \\
\hline Between 2 to 10 & 18 \\
\hline More than Ten & 0 \\
\hline
\end{tabular}

From table6 we can see that number of people trained on fire fighting and related protection activities, so that when ever any fire accident occurs, they can evacuate and area and help other co-workers to evacuate and try to minimize the fire propagation with necessary measures. They can minimize the loss to human life and goods stored.

Table 7: Showing the Details of Fire Accidents Took Place if Any

\begin{tabular}{|l|c|}
\hline $\begin{array}{c}\text { Number of Fire Accidents Took } \\
\text { Place Since Inception }\end{array}$ & $\begin{array}{c}\text { \% of Cold Stores Fire Accidents } \\
\text { Took Place }\end{array}$ \\
\hline One to five minor & 22 \\
\hline One major & 6 \\
\hline Two to five Major & 0 \\
\hline More than Five minor & 0 \\
\hline More than Five major & 0 \\
\hline
\end{tabular}

Table 7 gives the fire accident details in different stores. Mostly the accidents are minor in nature, except $6 \%$ cases with one major accident. 
Table 8: Details of Stores Provided with Automatic Fire Alarm System

\begin{tabular}{|l|c|}
\hline $\begin{array}{c}\text { Fully Automatic Fire Alarm System } \\
\text { Installed }\end{array}$ & $\begin{array}{c}\text { \% of Stores Provided with } \\
\text { Automatic Fire Alarm System }\end{array}$ \\
\hline Yes & 26 \\
\hline No & 74 \\
\hline
\end{tabular}

From table 8 it can be seen that automatic fire alarm system is provided at only $26 \%$ of stores, indicates the need to alarm the store operators to install such systems. This will help to indicate the fire automatically. This is a better system than MCP's, and becomes best system for fire indication during non-working hours.

Table 9: Details of \% of Stores Provided with Pressurized Water Hydrant System

\begin{tabular}{|l|c|}
\hline $\begin{array}{c}\text { Pressurized Hydrant System Installed } \\
\text { and Operational }\end{array}$ & $\begin{array}{c}\text { \% of Cold Stores Installed with } \\
\text { Hydrant System }\end{array}$ \\
\hline Yes & 36 \\
\hline No & 64 \\
\hline
\end{tabular}

Pressurized water hydrant system is provided in almost all big cold stores, however small cold stores water hydrant system is not provided, and these cold stores appear very old. This indicates the alarming need of suitable fire prevention system. However these stores are provided with extinguishers of all three types Class A, B and C.

Table 10: \% of Cold Stores Provided with Packing Material Storage Area

\begin{tabular}{|l|c|}
\hline $\begin{array}{c}\text { Is there a Storage Area for Storing Paper, Wood and } \\
\text { CFB Cartons, etc., within the Cold Store Area }\end{array}$ & $\begin{array}{c}\% \text { of Stores with Storage Area } \\
\text { for Packing Materials }\end{array}$ \\
\hline Yes & 78 \\
\hline No & 22 \\
\hline
\end{tabular}

From table 10, it is found that majority of cold stores are handling and storing packaging materials like paper, foam, paper pulp trays for apples, corrugated fiber board cartons, wooden boxes etc. This is the main source of fire accidents. Suitable fire detection and fire fighting mechanisms to be provided like hydrant system, sprinkler system.

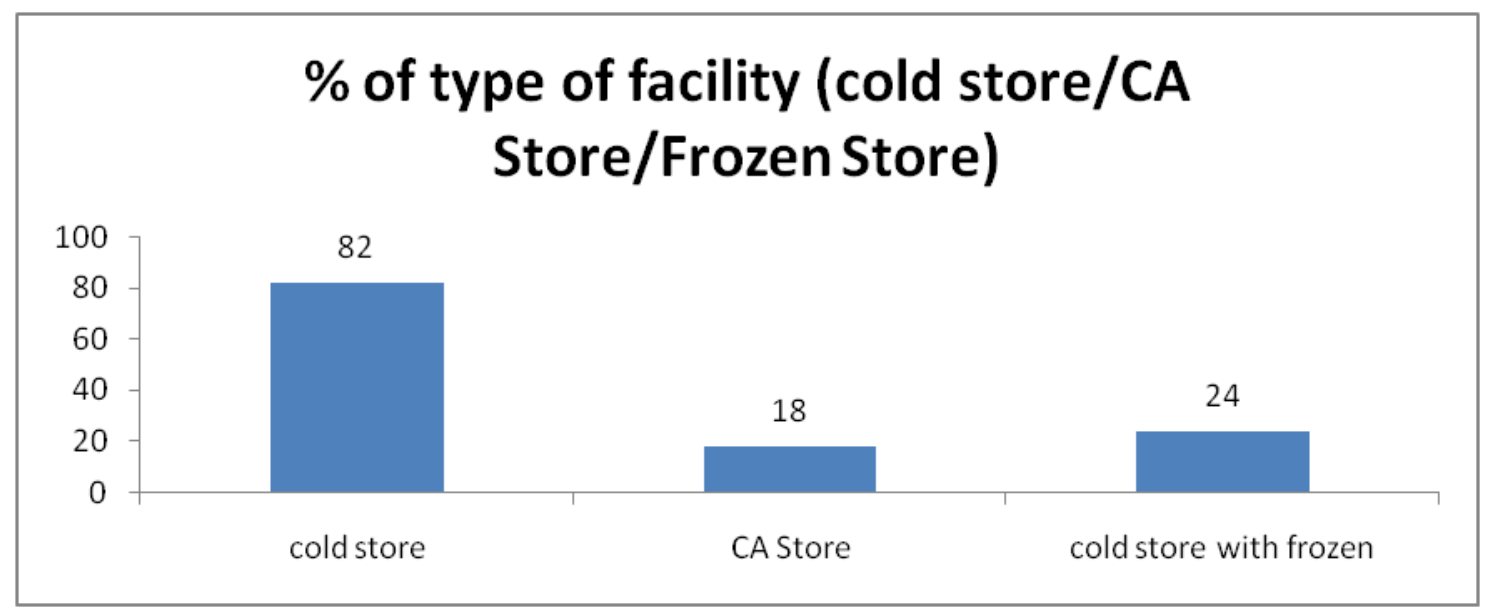

Figure 1 


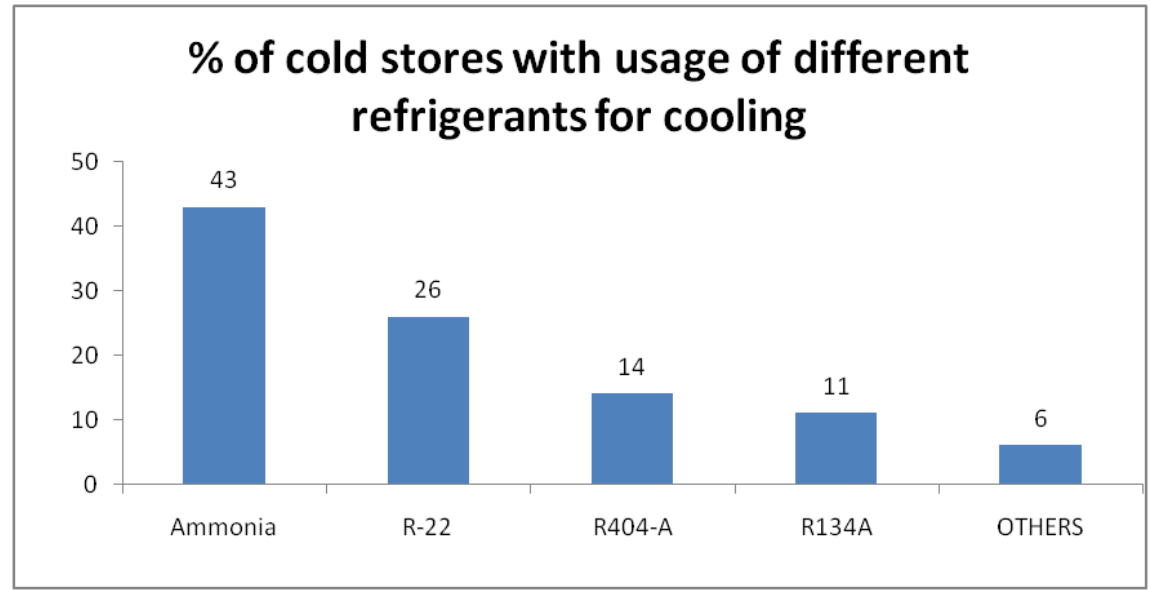

Figure 2

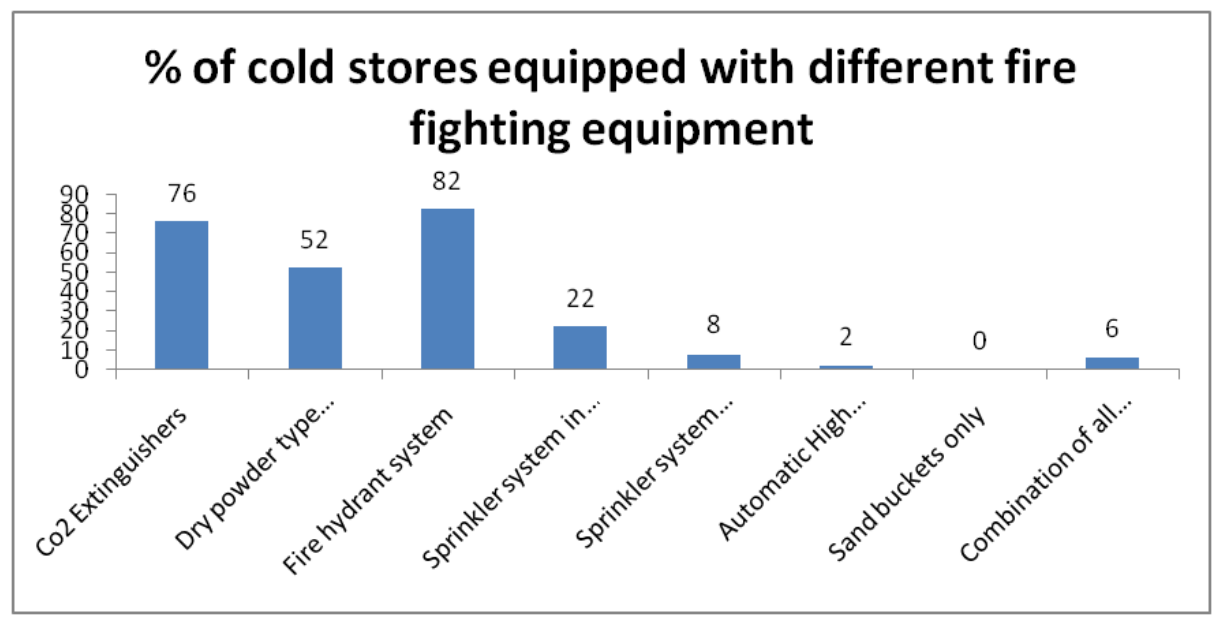

Figure 3

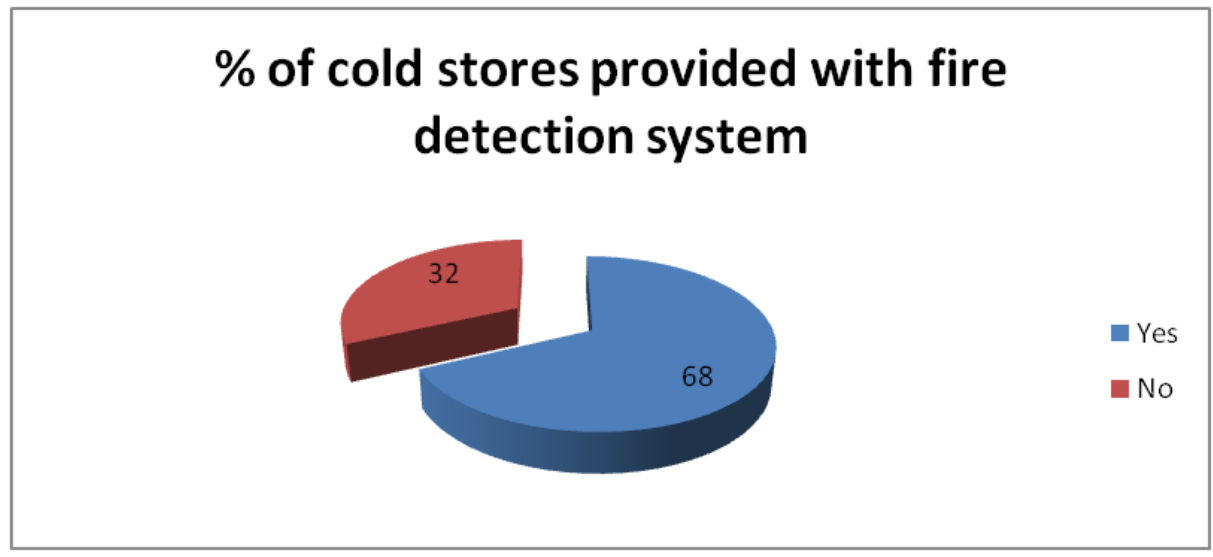

Figure 4 


\section{$\%$ of cold stores provided with MCP's}

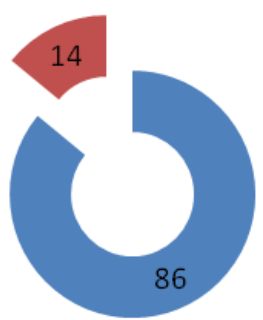

Figure 5

\section{$\%$ of stored with trained people on fire safety}

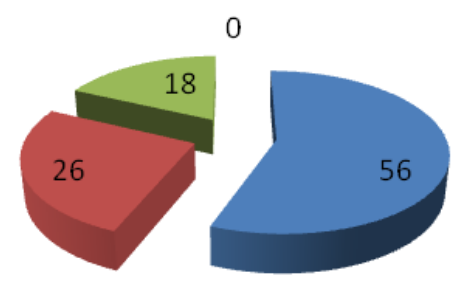

One

Two

Between 2 to 10

more than Ten

Figure 6

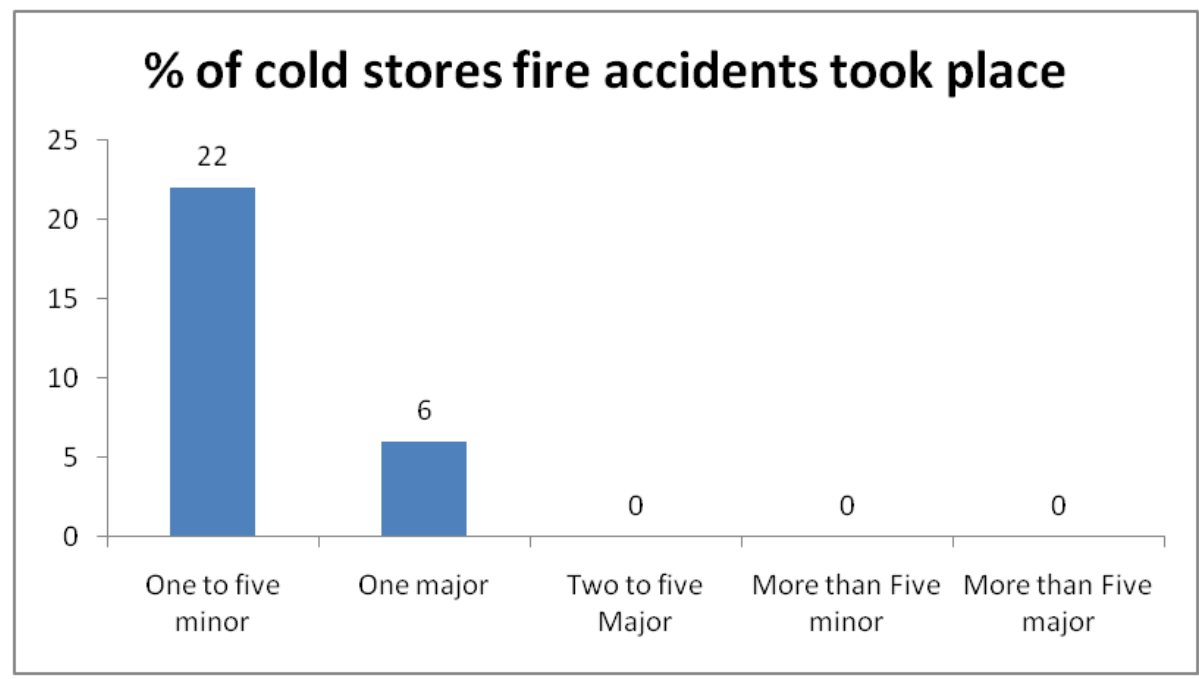

Figure 7 


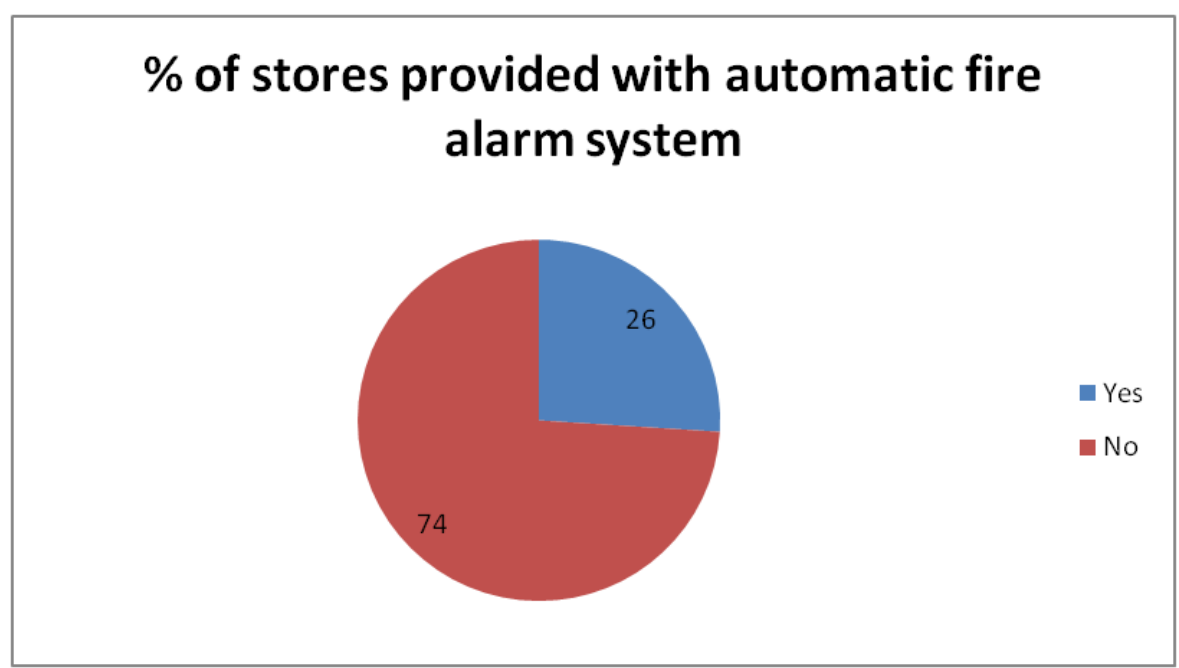

Figure 8

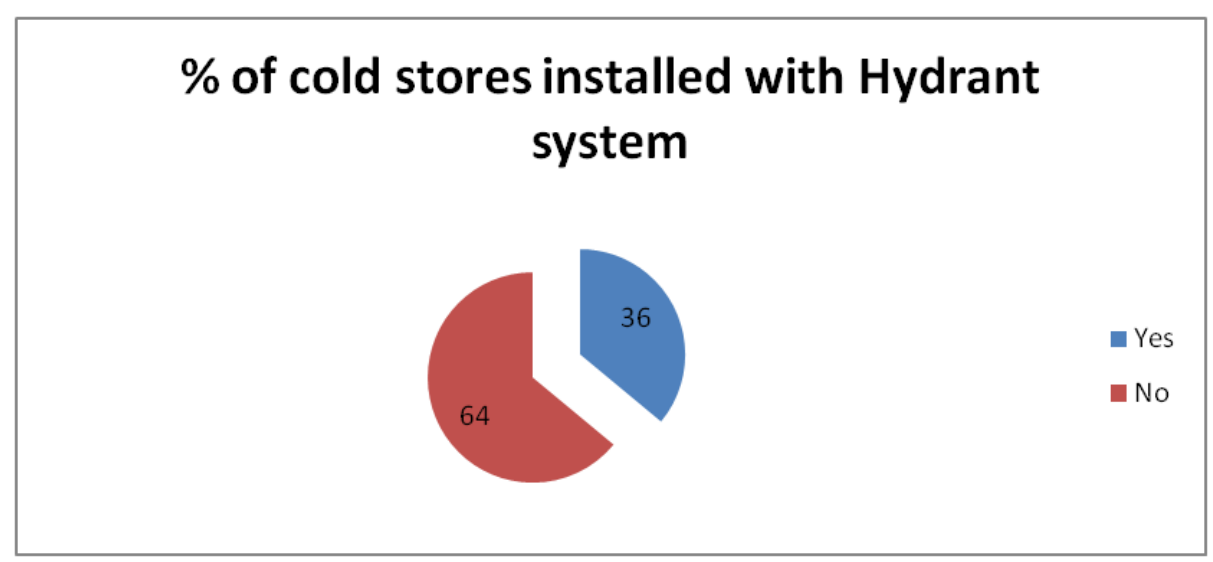

Figure 9

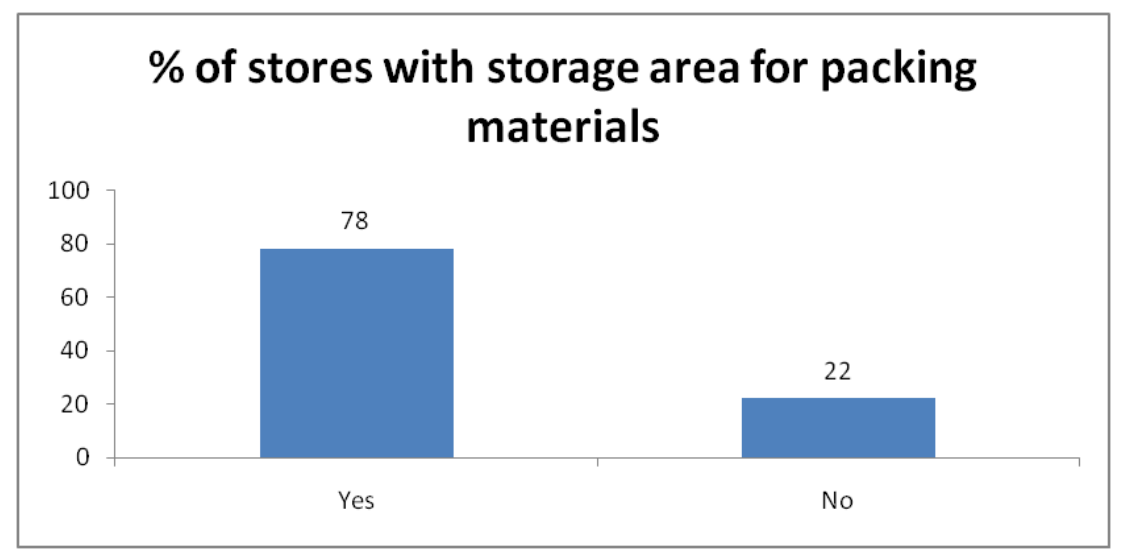

Figure 10

It is seen from the data above that majority of the cold stores preserving fruits and vegetables and other agriculture crops are provided with one or other fire safety systems for safety protection in case of fire. However scientific approach is found missing in most of the stores. i.e., use of suitable fire detection and fire extinguishing based on type of fire and kind of machinery and materials storage areas. An electrical switch room or transformer (indoor) or stabilizers need foam type automatic system, which was found in only one cold store. Class $\mathrm{A}, \mathrm{B}$ and $\mathrm{C}$ and $\mathrm{CO}_{2}$ type extinguishers need to be 
maintained with sufficient number at prescribed locations and to be checked time to time for their functioning.

\section{CONCLUSIONS}

Kyoto and Montreal protocol (on reducing ozone depletion and global warming) necessitated the use of better refrigerants in all refrigeration and air-conditioning systems. Cold stores and controlled atmosphere storages used lot of refrigerant gases and any leakage can make harm to the environment. Existing refrigerants based on CFC's to be replaced with hydrocarbon refrigerants, so there is an urgent need to make arrangements for fire proof systems to avoid accidents arising from use of hydrocarbons for refrigeration. Considering the above situation, the following recommendations are made.

- Use of spark proof electrical systems, especially the contact less switches, relays and thermostats ( as the leakage of hydrocarbon gases can catch fire in case of sparks from relays, thermostats or other electrical devices)

- Use of combination fire detection and fire fighting systems in place of simply depending on Type A,B,C fire fighting cylinders

- Training of technicians on retrofitting of refrigeration systems to go for better and safe refrigerants to save environment, at the same time hydrocarbon refrigerants need to be handled carefully (Propane, Butane, Pentane, etc.,)

- Devising and providing fire safety manual in each and every cold store

- Conducting fire drill to check all Pressuring water hydrants are in working condition

- Creating awareness among technicians and labor working in packing and grading of fruits in the cold store area

- Creating awareness among workers to keep packing material at designated place in the cold store and more safety arrangements made in fire prone packaging material storage areas.

\section{REFERENCES}

1. Ramesh Babu, D. (2014), Technological aspects of controlled atmosphere storage - Implementation for Indian produce by FHEL/CONCOR, proceedings of National conference on "Innovations and challenges in processed food in India", IndoAmerican chamber of commerce, New Delhi. https://scholar.google.co.in/citations?user=t_LqilkAAAAJ\&hl=en.

2. ASHRAE Handbook (1990) Atlanta, Ga: American Society of Heating, Refrigerating and Air Conditioning Engineers.

3. P. Persson, O. Arvidsson, K. ödéen (1980) Fire risks and fire prevention in cold stores, international journal of refrigeration, volume 3, issue 5: 295-298.

4. Joshi, Yogesh G., and DR Dinesh R. Zanwar. "Thermodynamic Evaluation of Vapor-Compression Refrigeration System with Theoretical Exergy. "International Journal of Mechanical and Production Engineering Research and Development (IJMPERD) 9, Special Issue, Jun 2019, 74-79

5. Dragan Živanić, Nikola Ilanković, AtilaZelić (2019) fire safety measures in warehouses, 16th international conference of occupational health and safety ohrid, north Macedonia 9-12 October 2019.

6. E. Ramesh, D. Ramesh Babu and P. Ramchandar Rao,(2018) The Impact of Project Management in Achieving Project SuccessEmpirical Study, International Journal of Mechanical Engineering and Technology, 9(13), pp.237-247, http://www.iaeme.com/IJMET/issues.asp? JType=IJMET\&VType=9\&IType=13 
7. Kumar, Dipu, and Mohammad UL Hassan. "Experimentation and Performance Evaluation of Heat Recovery from Domestic Refrigerator. "International Journal of Mechanical Engineering (IJME) 7. 3, Apr - May 2018; 41 - 50

8. Siva Rama Krishna, L, Mahesh, V, Sandeep Dulluri and Rao, C. S.P. (2010) Implementation of an online scheduling support system in a high mix manufacturing firm, International Journal of Engineering, Science and Technology, Vol. 2, No. 11, pp. 90 103.

9. S Dulluri, V Mahesh, CSP Rao,(2008) A heuristic for priority-based scheduling in a turbine manufacturing job-shop, International Journal of Industrial and Systems Engineering 3 (6), 625-643.

10. Suman Kumar Naredla, P. V. Raja Shekar, D Ramesh Babu and Sridhar Condoor, (2018). Uniquely Addressing Customer Pain Points - the Case Study of Agritech App, International Journal of Mechanical Engineering and Technology,9(11),pp.23062314.http://www.iaeme.com/IJMET/issues.asp?JType=IJMET\&VType=9\&IType=11.

11. P Sammaiah, D Ramesh Babu, L Radhakrishna, and P Rajendar (2019). Kinetics of Moisture Loss during Dehydration of Drum Stick Leaves (MoringaOliefera) In a Bio-Mass Tray Dryer. International Journal of Engineering and Advanced Technology (IJEAT) ISSN: 2249 - 8958, Volume-8 Issue-6, August, 2019.

12. Sharma, Ankush, and Jagdev Singh. "Experimental investigation of refrigerant flow rate with spirally coiled adiabatic capillary tube in vapour compression refrigeration cycle using eco friendly refrigerant." International Journal of Mechanical and Production Engineering Research and Development 3 (2013): p85-94.

13. D. Ramesh Babu, K. V. Narasimha Rao and SyamKolati (2019) The Design of Refrigeration, Thermal Insulation and an Equipment for Healthy Ripening of Mango and Banana Without Using Harmful Chemicals. International Journal of Mechanical and Production Engineering Research and Development (IJMPERD), ISSN (P): 2249-6890, Vol. 9, Issue 1, Feb 2019, 423-434.

14. Khan, S., Abdul Aabid, and Maughal Ahmed Ali Baig. "Design and Fabrication of Unmanned Arial Vehicle for Multi-Mission Tasks." Int J Mech Prod Eng Res Dev 8 (2018).

15. Ramesh Babu, D., Narasimha Rao, K. V., Satish Kumar, M. V. and Satish Kumar, B., "Handling of Apples During Sortinggrading Operation and Measuring the Mechanical Properties Firmness after Controlled Atmosphere Storage”, International Journal of Mechanical and Production Engineering Research and Development (IJMPERD), (2018), vol. 8, no.6, pp. 617-634

16. Narasimha Rao KV, Shareef Shaik and Ramesh Babu. D, "Mathematical Modeling of Cooling Rates of Mango Fruits during Unsteady State Cooling in An Artificial Ripening Chamber", Test Engineering and Management, (2020), March-April, Vol. 83, pp. 6862-6871.

17. Narasimha Rao K V, SasankDevarakonda and Ramesh Babu D, "Mathematical Modeling of Cooling Rates of Mango Fruits During Unsteady State Cooling in An Artificial Ripening Chamber", Test Engineering and Management, (2020), March-April, Vol 83, pp. 6872-6879.

18. D Ramesh Babu, K V Narasimha Rao, E Ramesh and T Sabitha, Awareness on Food Processing Entrepreneurship among Engineering Faculty, International Journal of Engineering and Advanced Technology (IJEAT) ISSN: 2249 - 8958, Volume-8 Issue-6, August 2019, pp 1207-1216.

\section{AUTHOR'S PROFILE}




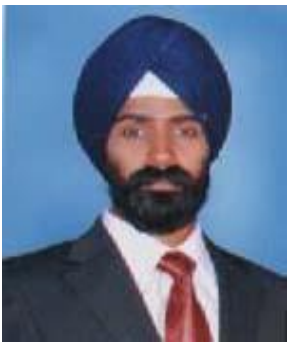

Mr.SardarParminder Singh currently working as Asst. Professor in Department of Business Management at S. R. Engineering College (SREC), Warangal. He has 8 years of experience in Industry in the field of Marketing and 4 years in teaching (12 yrs). He obtained MBA Degree from ICFAI University. He published 5 papers in various journals. His research areas include Design of Distribution channels, Sales promotion, Fire systems and Supply chain management.

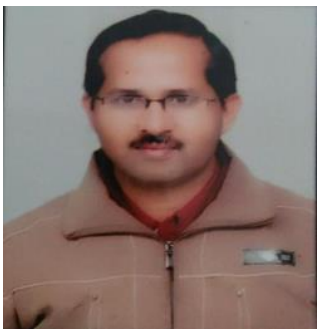

D. Ramesh Babu has got over 24 years of professional experience in manufacturing, research, maintenance, consultancy and project management of Refrigeration, Cold Storage and Controlled Atmosphere storage technologies.

He was graduated in Mechanical Engineering from JNTU College of Engineering, Hyderabad in the year 2000 and obtained MBA in production and operations management from MDU, Rohtak. He also obtained his MTech in Advanced Manufacturing from JNTU, Hyderabad. He has got expertise in refrigeration, fruit preservation and food processing. He is presently working as Assistant Professor in Mechanical Engineering at S R Engineering college, Warangal since year 2014. He has four years of experience in refrigeration equipment manufacturing at Voltas Limited, seven years of experience in fruit preservation at Defence food research laboratory, DRDO-Mysore and worked for eight years at cold chain project of CONCOR before joining teaching.

He is a recipient of DRDO cash award in the year 2003. He was nominated by CONCOR for eight days visit to ISRAEL as part of cold chain project for preservation of apples in the year 2011. He has published 4 research papers in SCI indexed journal and 9 papers in SCOPUS indexed journals and 6 in ICI indexed journals. He also presented numerous papers at various International and national conferences. His paper got best paper award by the TJPRC for the paper on "The Design of Refrigeration, Thermal Insulation and an Equipment for Healthy Ripening of Mango and Banana without Using Harmful Chemicals." published in IJMPERD.

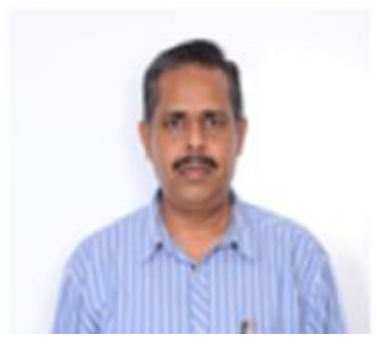


Dr P. Issac Prasad, has 22 years of experience and working as Professor in the Department of Mechanical Engineering, KLEF (Deemed to be University), Vaddeswaram. He obtained Doctoral degree from JNTUA in the field of Thermal Engineering. He acted as Thermal Engineering Research Group head in the Department of Mechanical Engineering, KLEF. He worked as Principal at two Engineering Institutions affiliated to JNTUK and JNTUA. Apart from conference, national and international publications, at present he is also acting as Associate Dean - IQAC, KLEF.

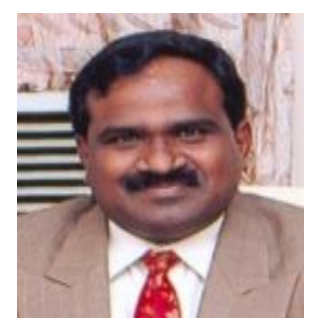

Dr K V Narasimha Rao is a senior Professor with 27+ years experience in Academic, Consultancy and Industry and has been working with KLEF (Deemed to be University) Vaddeswaram since 2 September 2016. DrNarasimha Rao was graduated in Mechanical Engineering from Regional Engineering College, Warangal in 1986 and went on to obtain Master's and Doctoral degrees from the Indian Institute of Science, Bangalore during 1990 and 1995 respectively in the field of Thermal Engineering. He worked for seven years (1995-2002) as Research Associate and Fellow, Industrial Energy Group at Tata Energy Research Institute (teri), Southern Regional Centre, Bangalore before moving into Academics in 2002. Prior to joining KLEF, he worked at few Engineering Colleges as Principal/Director/Dean.Dr Rao has published 40 scientific papers (three in SCI Listed Journals, 30 Scopus indexed Journals and Chapter 10 in Recent Advances in Material Sciences, Lecture Notes on Multidisciplinary Industrial Engineering) and numerous technical reports for various National/International Agencies. HE has filed 14 patents (three published).

\section{Membership of Professional Bodies}

Dr Rao is a member of ASHRAE, ISCA, ISHMT, ISHRAE, ISTE \& SESI and Fellow of Institution of Engineers (India).

\section{Scholarships \& Awards}

- $\quad$ Recipient of 'National Merit Scholarship' during 1980-85 (6 Years).

- Recipient of 'Special Rank' in Mathematics Olympiad conducted by Andhra Pradesh Association of Mathematics Teachers (APAMT), Hyderabad, A. P. at Senior Level during 1980-81.

\section{Areas of Specialization}

- Energy Auditing, Energy Conservation \& Management, Heat Transfer, Refrigeration \& Air-conditioning and Renewable Energy Sources.

\section{Research Guidance}

Supervised 14 M. Tech. Students and presently guiding Six PhD Scholars and four M. Tech. Students.

\section{Important Projects Handled}

- Dr Rao was the Team Leader for the Consultancy Assignment on Energy Efficiency Services-Phase-III (3 May-30 November 1998), for the Ministry of Industry, His Majesty's Govt. of Nepal, Industrial Energy Management 
Component of the Power Sector Efficiency Project (PSEP) - IDA Credit No. 2347-NEP, World Bank. The activities included Demand Side Management (DSM), Furnace \& Kiln and Boiler Efficiency studies, Co-generation Feasibility studies covering 65 major industries in Nepal. Trained 11 Nepalese Engineers as Certified Energy Auditors as part of the Consultancy Assignment.

- Dr Rao was involved in the field-testing of a number of Energy Saving Devices / Retrofits under the Energy Saving Demonstration Project, funded by GTZ, Germany.

- Dr Rao has developed and Demonstrated "Performance Contract for Industrial Energy Management" for Indian Scenario, sponsored by Canadian International Development Agency. 

